\title{
The Use of CORONA Images in Remote Sensing of Periglacial Geomorphology: An Illustration from the NE Siberian Coast
}

\author{
Guido Grosse, ${ }^{1 *}$ Lutz Schirrmeister, ${ }^{1}$ Viktor V. Kunitsky ${ }^{1,2}$ and Hans-Wolfgang Hubberten ${ }^{1}$ \\ ${ }^{1}$ Alfred Wegener Institute for Polar and Marine Research, Research Unit Potsdam, Germany \\ ${ }^{2}$ Permafrost Institute, Russian Academy of Science, Siberian Branch, Yakutsk, Yakutia, Russia
}

\begin{abstract}
CORONA images have been used for the mapping of periglacial features on the Bykovsky Peninsula and adjacent Khorogor Valley in northeast Siberia. Features, mapped and analysed within a geographical information system, include thermokarst depressions, thermo-erosional valleys, thermo-erosional cirques, thermokarst lakes, thermokarst lagoons and pingos. More than $50 \%$ of the area is strongly influenced by thermally-induced subsidence. Thermokarst in the area is probably less active today than in the early-middle Holocene. Copyright (C) 2005 John Wiley \& Sons, Ltd.
\end{abstract}

KEY WORDS: remote sensing; thermokarst; GIS; NE Siberia; geomorphology

\section{INTRODUCTION}

Diverse remote sensing methods have been employed in Arctic periglacial research in the last few years. These include vegetation mapping (e.g. Walker, 1999; Brook and Kenkel, 2002; Hope et al., 2003; Tommervik et al., 2003), change detection (e.g. Rees et al., 2003; Rigina, 2003; Yoshikawa and Hinzman, 2003; Stow et al., 2004) and mapping of general permafrost properties (e.g. Morrissey et al., 1986; Peddle and Franklin, 1993; Leverington and Duguay, 1997; Lewkowicz and Duguay, 1999; Etzelmüller et al., 2001). Investigations of permafrost and periglacial geomorphology in the Arctic hemisphere were usually associated with the use of high-resolution aerial imagery (e.g. Cabot, 1947; Frost et al., 1966; Mollard, 2000; Boike and Yoshikawa, 2003). But the spatial and temporal coverage of such imagery is often limited. For the large Russian part of the Arctic, aerial imagery and detailed topographic maps are often still classified or not available. This paper describes the use of easily-available, high-resolution CORONA satellite photography as a substitute for aerial imagery in

* Correspondence to: G. Grosse, Institute for Polar and Marine Research, Alfred Wegener Unit, Telegrafenberg, A43, D-14473 Potsdam, Germany. E-mail: ggrosse@awi-potsdam.de northeast Siberia. The high-resolution mapping of thermokarst features from CORONA imagery is the basic input for any geographic information system (GIS) of the investigation area.

\section{THE CORONA PROGRAMME AND ITS SATELLITE IMAGES}

CORONA satellite imagery first became available in 1995. In 2002, subsequent images similar to imagery from the CORONA programme (1963-1980) were declassified. The satellite images of varying ground resolution $(0.6 \mathrm{~m}$ to $150 \mathrm{~m})$ are available from the USGS Earth Resources Observation Systems (EROS) Data Center in Sioux Falls, South Dakota (http:// edc.usgs.gov) (Table 1).

CORONA imagery has been used for several years for different scientific purposes and in different regions of the world. Most applications dealt with archaeological research (e.g. Kennedy, 1998; Goossens et al., 2001; Philip et al., 2002) and geoscientific research (Tappan et al., 2000; Altmaier and Kany, 2002). Some worked with this imagery in polar regions (Bindschadler and Vornberger, 1998; Rigina, 2003).

Received 20 September 2003 Revised 27 April 2004

Copyright (C) 2005 John Wiley \& Sons, Ltd.

Accepted 8 August 2004 


\section{INVESTIGATION AREA}

The Bykovsky Peninsula and adjacent Khorogor Valley are part of the recent coastal lowland of the Laptev Sea (Figure 1). They belong to two separate geological regions - the Karaulakh mountain range in the west (Khorogor Valley) and a Pleistocene accumulation plain in the east (Bykovsky Peninsula). In the Khorogor Valley, the features of interest are mainly situated in the lower valley regions (Figure 2). Of the total investigation area of $258.7 \mathrm{~km}^{2}$, two thirds belong to the Bykovsky Peninsula and one third to the Khorogor Valley. The permafrost in this region is continuous and reaches depths of $300-500 \mathrm{~m}$. The active layer is up to $30-50 \mathrm{~cm}$ thick. The relief of the Bykovsky Peninsula is dominated by flat elevated areas up to $40 \mathrm{~m}$ a.s.l., together with thermokarst depressions down to sea level. Coastal erosion, mainly a combination of thermal erosion and coastal abrasion, produces steep cliffs up to $40 \mathrm{~m}$ in height.

Many authors have described thermokarst and its impact in Siberia (e.g. Soloviev, 1973; Czudek and Demek, 1970; Romanovskii et al., 2000) and other periglacial regions in North America (e.g. Mackay, 1962; French, 1974; Murton, 1996).

Several palaeo-environmental studies with a multidisciplinary focus have been conducted in the area by Russian and German colleagues during the last few years (Romanovskii et al., 2000; Schirrmeister et al., 2001a; Schirrmeister et al., 2002; Meyer et al., 2002; Siegert et al., 2002; Andreev et al., 2002). Most have investigated outcrops on the east shore of the Bykovsky Peninsula, especially at the Mamontovy Khayata site (Figure 2). Some authors have published

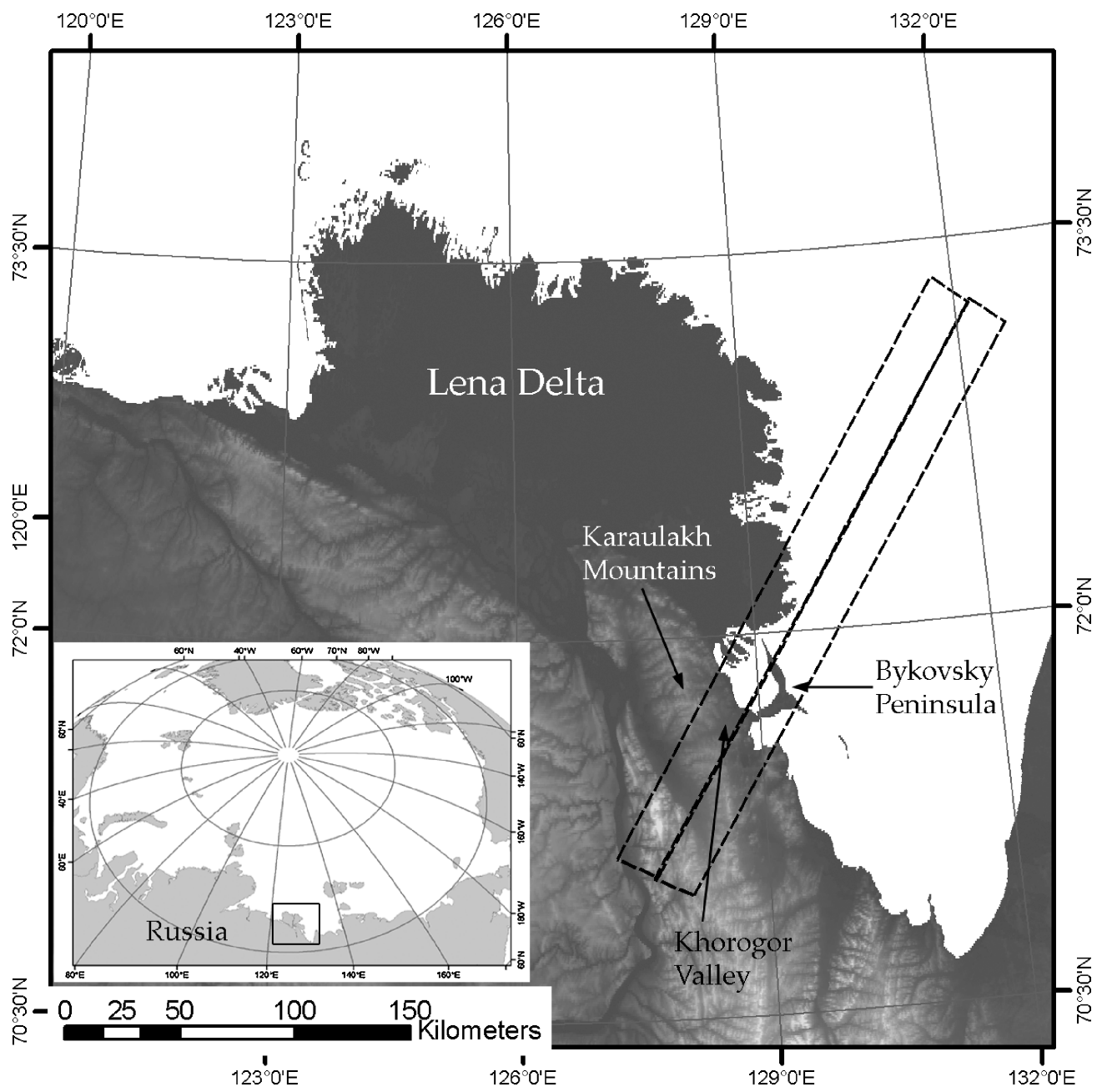

Figure 1 Location of the investigation areas of Bykovsky Peninsula and Khorogor Valley. The dashed rectangles mark the coverage of the two CORONA image stripes used in this work (map after GLOBE30 DEM data). 


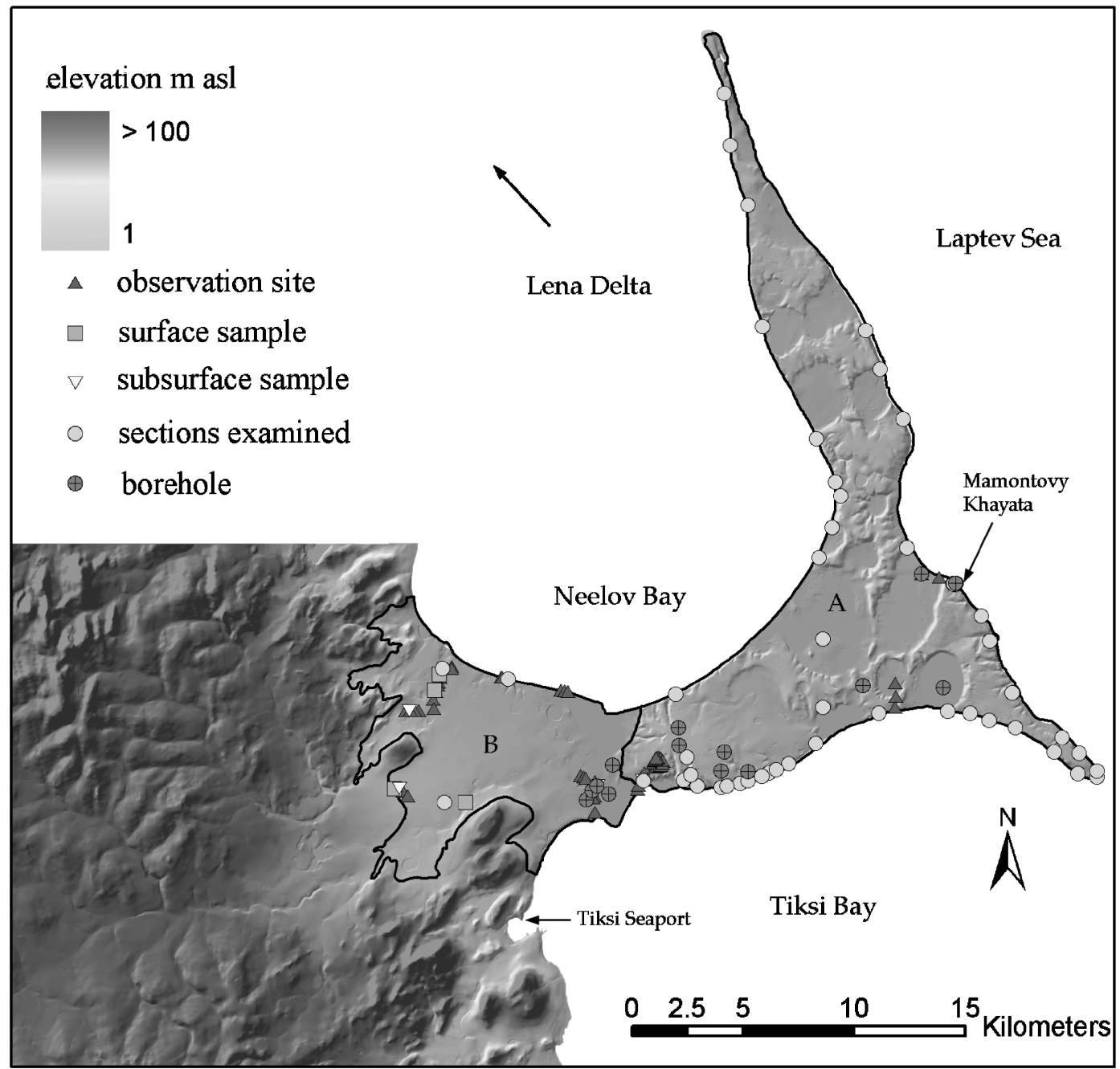

Figure 2 DEM of the investigation area, illuminated from the upper left; A-Bykovsky Peninsula, B — Lower Khorogor Valley up to the $50 \mathrm{~m}$ elevation contour. The various field sites with geocryological ground truth data originate from our own fieldwork and the fieldwork of other authors (Kunitsky, 1989; E. A. Slagoda, unpublished dissertation, 1993; Grigoriev, 1993).

Table 1 Technical characteristics of the CORONA KH4B camera system.

\section{Satellite KH-4B}

\begin{tabular}{ll}
\hline Period of operation & $15 / 09 / 1967-25 / 05 / 1972$ \\
Camera type & $\mathrm{J}-3$, panchromatic \\
Flight altitude & $150 \mathrm{~km}$ \\
Focal length & $61 \mathrm{~cm}$ \\
Frame format & $5.5 \mathrm{~cm} \times 75.7 \mathrm{~cm}$ \\
Film resolution & $160 \mathrm{lines} / \mathrm{mm}$ \\
Photo scale of the film & $1: 247,500$ \\
Ground coverage & $13.8 \mathrm{~km} \times 188 \mathrm{~km}$ \\
Best ground resolution & $1.8 \mathrm{~m}$ \\
\hline
\end{tabular}

geocryological field data from this area in the Russian literature (e.g. Kunitsky, 1989; E. A. Slagoda, unpublished dissertation, 1993; Grigoriev, 1993). The only previously published work on remote sensing dealing in part with this area was conducted by Grosswald (1998), who presented geomorphological features on aerial images of the Tiksi region (southeast of the Lena Delta).

Fieldwork during the summers 1998, 2000 and 2002 (Siegert et al., 1999; Schirrmeister et al., 2001b; Grigoriev et al., 2003), and literature reviews, were important tools for the ground validation of the geomorphological structures visible on the CORONA images. 


\section{IMAGE PROCESSING}

Two cloud-free images where chosen, covering a region of about $5 \times 10^{3} \mathrm{~km}^{2}$ (Figure 1). The Bykovsky Peninsula and the Khorogor Valley are covered by a small subset of these images of about $1.4 \times 10^{3} \mathrm{~km}^{2}$; thus only parts of the image strips were used. Only a tiny area (about $1 \mathrm{~km}^{2}$ ) in the southeast of the Bykovsky Peninsula (Cape Muostakh) is not covered by these two images (Figure 3). The images were captured as parallel stripes by the CORONA KH-4B satellite system (Table 1) in July 1969. The image specifications are given in Table 2. The images were ordered as film negatives and scanned with a highresolution A3 transmitting-light scanner (Type AGFASCAN XY 15) to produce high-quality digital greyscale files. The maximum information return from digitalizing CORONA photography is reported

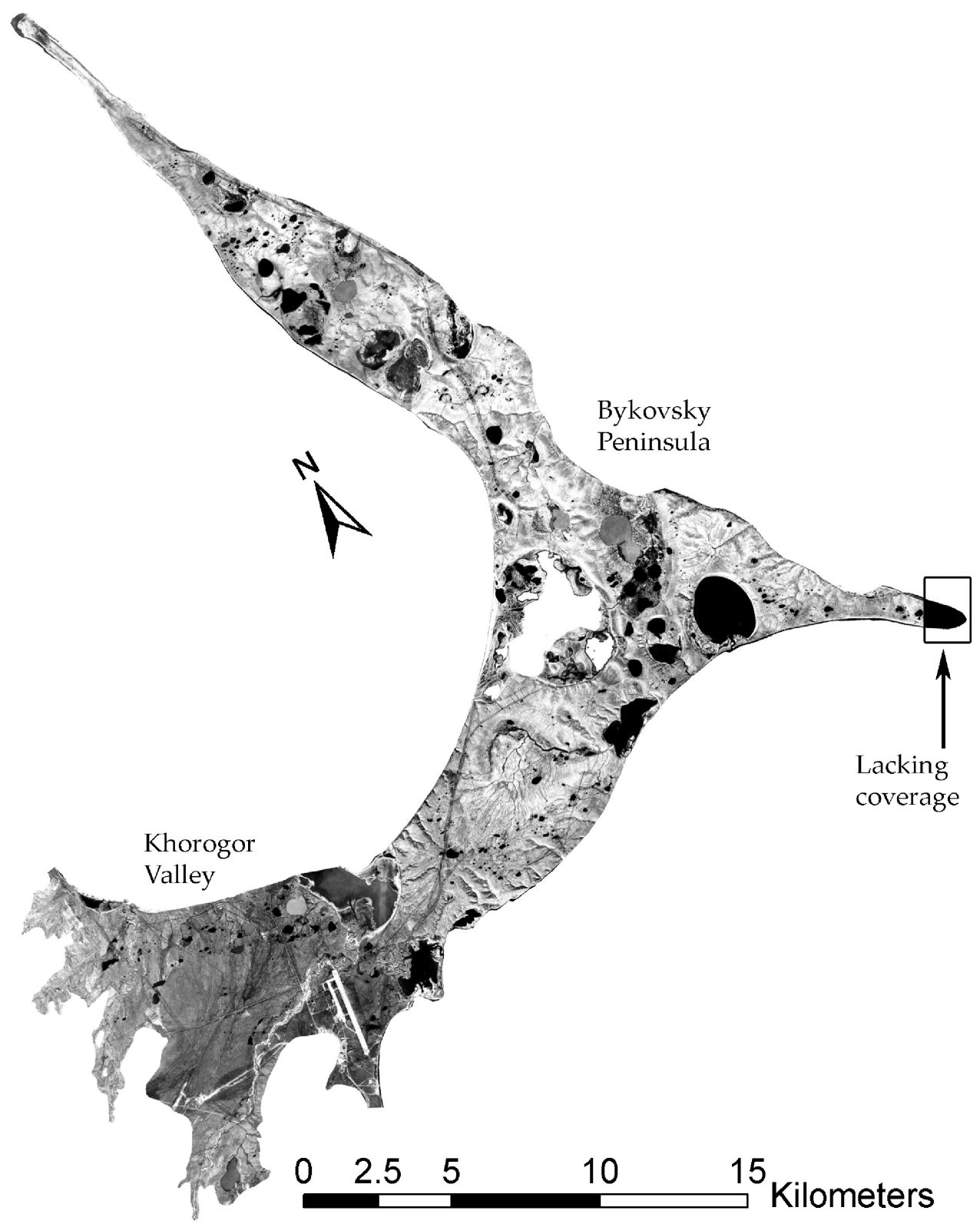

Figure 3 Panchromatic CORONA mosaic of the investigation area, based on two images from July 1969. 
Table 2 Image characteristics for the two satellite scenes used in this work.

\begin{tabular}{ll}
\hline CORONA images used & D003003M1107-1AFT \\
& D003002M1107-1AFT \\
\hline Date of acquisition & 24 July 1969 \\
Film size per image subset & $5.5 \times 14 \mathrm{~cm}$ \\
Ground coverage per subset & $13.8 \times 35 \mathrm{~km}$ \\
Scan resolution & $7 \mu \mathrm{m}(3600 \mathrm{dpi})$ \\
Ground resolution & $2.5 \mathrm{~m}$ \\
\hline
\end{tabular}

to be at a scan resolution of $4 \mu \mathrm{m}$ by Leachtenauer et al. (1998). They found no substantial loss of information up to a scan resolution of $15 \mu \mathrm{m}$, whereas file sizes were significant smaller. Thus, the scan resolution in this work was chosen with $900 \mathrm{dpi}$ and $400 \%$ enlargement. This corresponds to a total resolution of $3600 \mathrm{dpi}$ or about $7 \mu \mathrm{m}$.

The image subsets of each strip have different radiometric behaviour. Therefore, a radiometric correction was applied with the software ENVI ${ }^{\mathrm{TM}}$ version 3.6. Both image subsets were radiometrically corrected relative to each other. Then, by collecting tie points in the slightly overlapping subsets, the images were mosaicked. Finally a linear contrast stretching techique was employed for the whole mosaic to enhance visual interpretability. The pixels in the digital CORONA images consist of grey values from 0 (black) to 255 (white). Similar to panchromatic aerial imagery, a correlation of grey-scale value and surface reflectance is given, so the interpretation of surface parameters is possible. Coherent dark pixel values stand for low reflection and high absorption, light pixel values for high reflection and low absorption of sunlight. This information can be used for discrimination of water (high absorption) or barren land (high reflection) and the visual differentiation of soil moisture or geological features. Dependent upon sun azimuth and altitude, shadows occur in areas with strong relief. The shadows can be used for interpretation of geomorphological features (e.g. depth of valleys or slope inclination).

For geo-referencing, 82 ground control points (GCP) were identified across the CORONA mosaic for co-registration with a previously geo-referenced topographical map mosaic at $1: 100,000$ scale $(0.5 \mathrm{~mm}=50 \mathrm{~m}$ in reality). The topographical maps are based on aerial and field survey data from 19661994. To rectify the image mosaic to the map projection (Gauss-Krueger Pulkovo, 1942 zone 22, with datum Pulkovo, 1942), a polynomial warping function of third order and bilinear pixel resampling were used.
The overall RMS error for rectifying the CORONA mosaic was $16.86 \mathrm{~m}$, whereas the individual errors had a range from 1.98 to $28.83 \mathrm{~m}$. The RMS error of several times a pixel size is caused mainly by the use of medium resolution, poor quality scanned topographical maps for geo-coding and the lack of clearly identifiable GCPs, like buildings or road intersections. The final image is shown in Figure 3.

\section{MAPPING OF THERMOKARST AND WATER SURFACES}

To enhance desktop mapping and spatial analysis, a digital elevation model (DEM) was developed. It is based on manually digitized elevation data from the same topographical maps used for rectification of the CORONA mosaic. Within ArcInfo ${ }^{\text {TM }}$ the TOPOGRID tool was used for the generation of an elevation grid with $15 \mathrm{~m}$ cell size. A test for vertical accuracy of the DEM interpolation algorithm with 52 original elevation points from the map and their accordant grid cells revealed a mean vertical error of $+0.49 \mathrm{~m}$ in the DEM. The accuracy of the elevation model is considered useful for this and further work. Additionally, a slope map and a shaded relief map were calculated from the DEM. The DEM, slope map and shaded relief map were separately used as a $50 \%$ transparent overlay for the CORONA image to enhance the visual interpretation of geomorphological structures in the panchromatic image.

Thermokarst features that could be discriminated and interactively mapped from the CORONA mosaic within the desktop GIS included lakes, depressions, lagoons, gullies, slumps and pingos (Figure 4). Water surfaces were classified with a density-slicing algorithm. For this task we assumed that water surfaces have the lowest reflectance values in the panchromatic images. The density slice separates the grey values in the image according to a threshold value. Several grey value thresholds were tested and finally the one with the best visual separation of water from land was applied to classify the image. The result is a binary image containing only water and non-water pixels (Figure 5). This classification method for panchromatic imagery has several weak points. First, due to low sun elevations, shadows are strong in deep valleys or slumps and hence mis-classified as water. Second, due to the acquisition time in July, some large lakes were still covered by highly reflective lake ice, hence mis-classified as non-water. Third, some large lakes were strongly disturbed with sediment suspension, hence mis-classified as non-water. Finally, in small polygonal ponds, vegetation grows in the shallow 

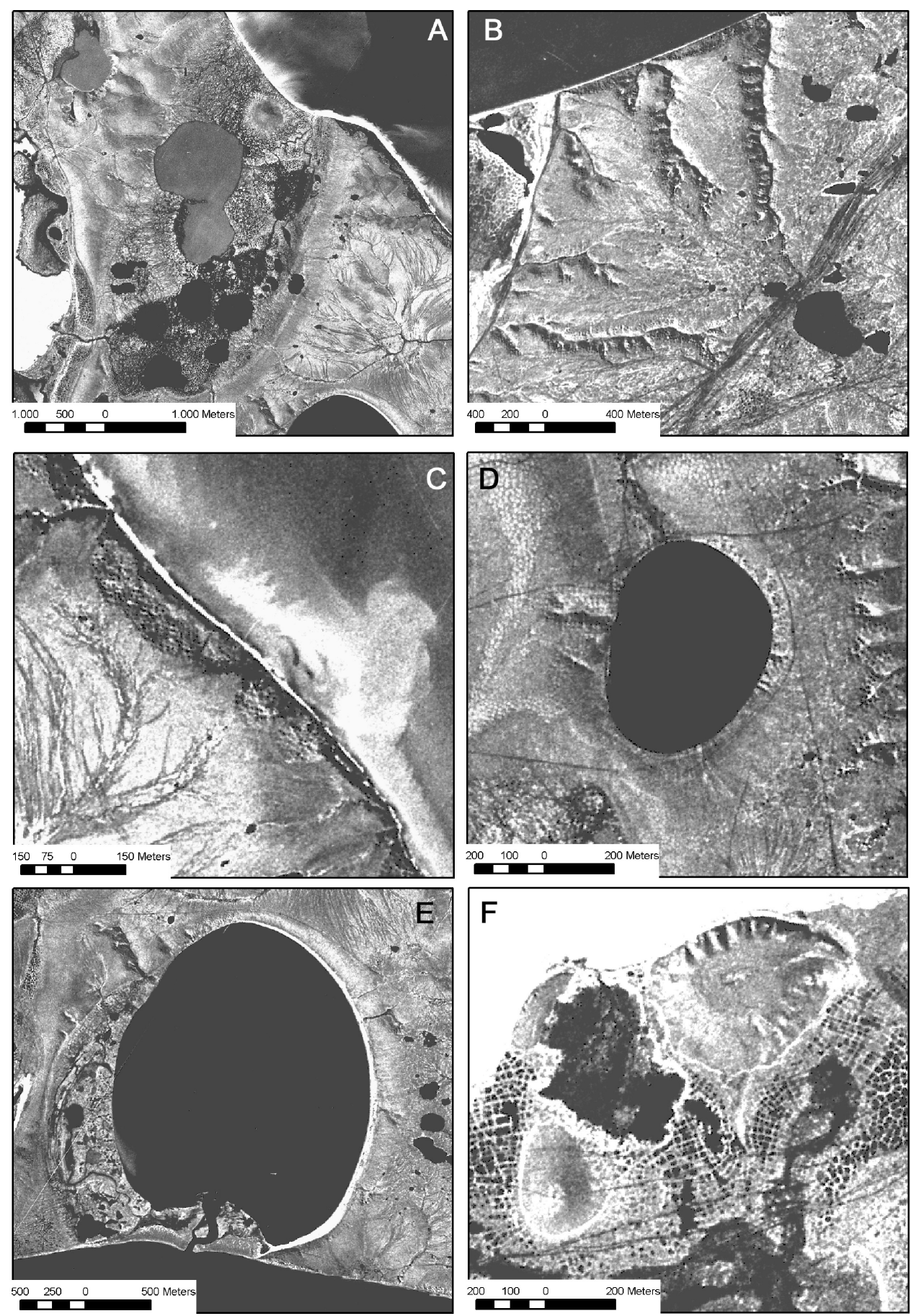

Figure 4 Geomorphological features identified from the CORONA images: A-Partially drained thermokarst depression due to coastal erosion with lake remnants and pingo. B - Gullies discharging from an upland surface and human-induced vehicle tracks. C-Large thaw slumps along the east shore of the Bykovsky Peninsula. D-Thermokarst lake with subsidence features on an upland plain. E-Lagoon in an early stage formed by coastal erosion and the drainage of a thermokarst lake (Ivashkina lagoon). F-Pingos and partially drained, lowcentred ice-wedge polygon terrain. 

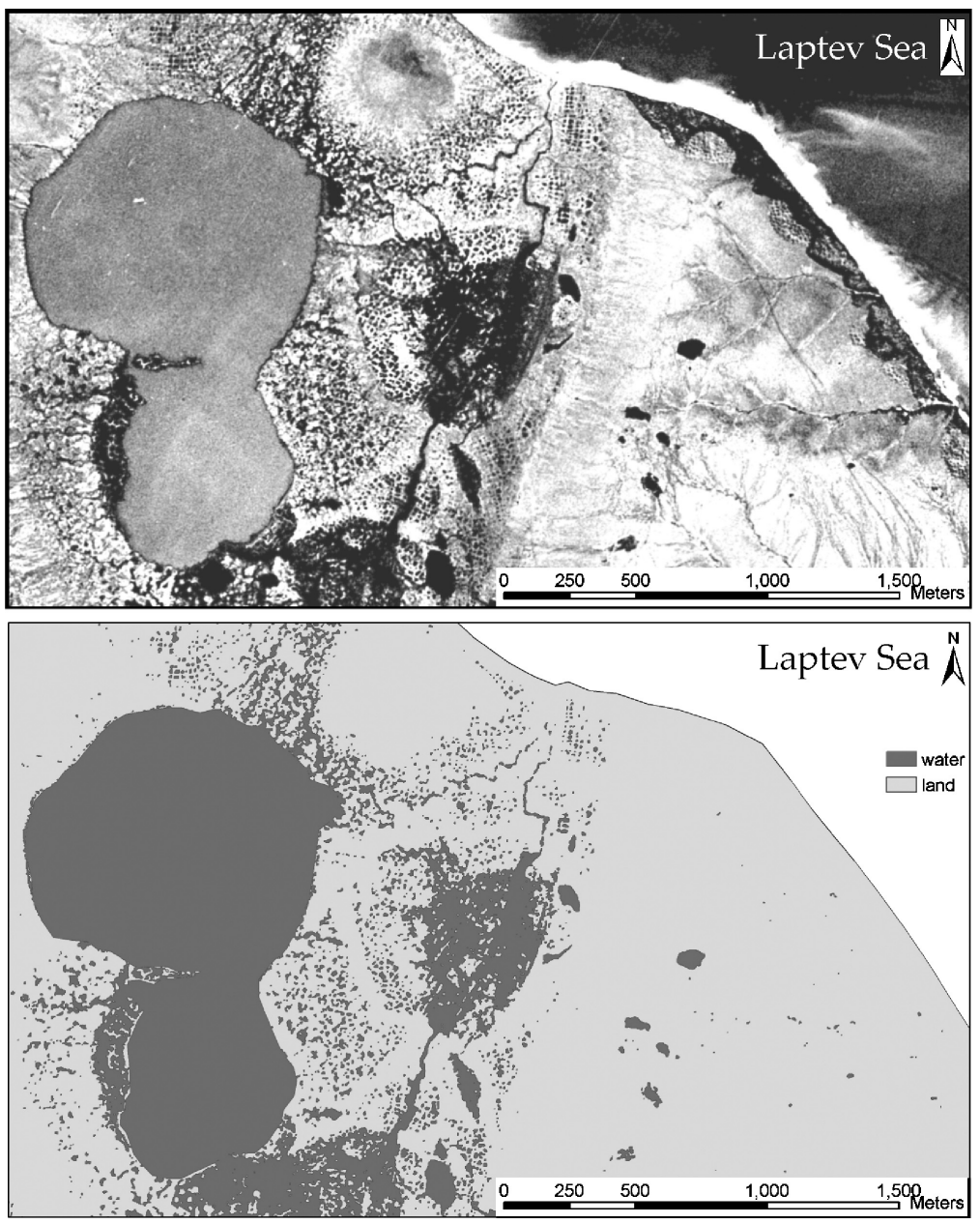

Figure 5 Classification of water surfaces in the thermokarst depression of Mamontovy Bysagasa (left part of image) and on the upland of Mamontovy Khayata (right part of image) on the east shore of the Bykovsky Peninsula: upper image-CORONA; lower imageinteractively corrected density-slice classification of inland water surfaces.

water and no exact boundary between water and non-water could be drawn. The first three types of mis-classification were corrected manually. According to the chosen threshold, the classification of lakes with vegetated boundaries results in minimum areas for such ponds. For an estimation of the waterclassification accuracy, the classified water surfaces were compared to the manually-mapped water surfaces and the digitized water surfaces from the topographical map (Table 3). The visually-examined and

Table 3 The different mapping methods reveal different results for the spatial extent of lakes and lagoons.

\begin{tabular}{llrrr}
\hline Feature & Source & Number & Area $\left(\mathrm{km}^{2}\right)$ & $\begin{array}{c}\text { \% of investigation } \\
\text { area }\end{array}$ \\
\hline Lakes and lagoons & Topographical map 1:100,000 & 397 & 30.143 & 11.7 \\
Lakes and lagoons & CORONA interactive mapping & 569 & 31.862 & 12.3 \\
Lakes & CORONA density slice classification & 25,050 & 26.362 & 10.2 \\
Lagoons & & 7 & 10.862 & 4.2 \\
Overall lakes and lagoons & & 25,057 & 37.224 & 14.4 \\
\hline
\end{tabular}


Table 4 Spatial properties and distribution of periglacial features mapped from the CORONA image mosaic.

\begin{tabular}{lrcccc}
\hline $\begin{array}{l}\text { Geomorphological } \\
\text { feature }\end{array}$ & Number & Area $\left(\mathrm{km}^{2}\right)$ & $\begin{array}{c}\text { \% of overall } \\
\text { investigation area }\end{array}$ & $\begin{array}{c}\text { \% of Khorogor } \\
\text { Valley area }\end{array}$ & $\begin{array}{c}\text { \% of Bykovsky } \\
\text { Peninsula area }\end{array}$ \\
\hline Thermo-erosional valleys & 145 & 11.188 & 4.3 & 0.2 & 6.3 \\
Thermokarst depressions & 16 & 80.713 & 31.2 & - & 46.1 \\
Thermo-erosional cirques & 7 & 1.170 & 0.5 & - & 0.7 \\
Pingos & 6 & 0.385 & 0.1 & - & 0.2 \\
\hline
\end{tabular}

manually-corrected classification result is considered the most accurate approximation for water surfaces.

\section{RESULTS}

The results for the mapping of periglacial features are shown in Table 4. In total, 145 valleys, 16 depressions, seven slumps, and six pingos were mapped (Table 4). By digitizing the 1:100,000 topographic map, 397 water bodies were detected. Manual mapping from the CORONA image detected 569 water bodies. Classification from the CORONA image detected 25,050 water bodies. The minimum lake area calculated from the topographic map and the manual CORONA mapping was $278 \mathrm{~m}^{2}$ and $186 \mathrm{~m}^{2}$, respectively. The minimum lake size for the classification was one pixel, which is about $6 \mathrm{~m}^{2}$. This small pond size is not necessary and not useful to implement into topographic maps, but nevertheless is an important factor in arctic tundra geo-ecosystems. The size distribution of the classified water bodies (lakes and lagoons) revealed a strong bias in area towards a few large lakes, but also a strong bias towards the number of very small lakes or ponds (Table 5). Water bodies $<400 \mathrm{~m}^{2}$ represent shallow polygonal ponds and small pools of meteoric water. The huge amount of such small ponds is responsible for increasing the total water surface in the investigation area to more than $6.5-7.2 \mathrm{~km}^{2}(+2.1-2.7 \%)$ compared to the topographic map and to manual mapping. Although 91\% of all lakes are represented by small ponds $<400 \mathrm{~m}^{2}$, they contribute only $5.9 \%$ of the total lake water surface.

Although most ponds are situated in the depressions, many ponds can also be found on the elevated plateaus, where drainage conditions are poorer. Large lakes and lagoons with more than $10,000 \mathrm{~m}^{2}$ coverage mainly occur in the basins of the central and the northern peninsula and at the isthmus between the Khorogor Valley and Bykovsky Peninsula. Only some large lakes have developed in the lower valley, the area of the biggest being less than $0.43 \mathrm{~km}^{2}$.

The area of the Bykovsky Peninsula occupied by lakes is only one third of the area occupied by thermokarst depressions. This shows that lakes must have been larger in the past. This is supported by the presence of pingos, several situated in the larger basin agglomerates in the central part of the peninsula (e.g. see Figures $4 \mathrm{~A}$ and $4 \mathrm{~F}$ ).

\section{CONCLUSIONS}

CORONA images are a cheap, efficient and easily available substitute for old aerial imagery. This makes them a valuable tool for preliminary investigations and pre-fieldwork mapping. In this paper we illustrate how the main periglacial surface features of a coastal lowland site in the Laptev Sea region can be distinguished and mapped with a mosaic of high-resolution

Table 5 Distribution of the spatial parameter area for lakes detected by density slice classification.

\begin{tabular}{lrccc}
\hline Lake type & Number & Area $\left(\mathrm{km}^{2}\right)$ & $\begin{array}{c}\text { In \% of total lake } \\
\text { number }\end{array}$ & $\begin{array}{c}\text { In \% of overall } \\
\text { lake area }\end{array}$ \\
\hline$\geq 10,000 \mathrm{~m}^{2}$ (large lakes) & 186 & 21.694 & 0.7 & 82.3 \\
$\begin{array}{l}<10,000 \mathrm{~m}^{2} \text { and } \geq 400 \mathrm{~m}^{2} \\
\text { (medium-small sized lakes) }\end{array}$ & 2081 & 3.104 & 8.3 & 11.8 \\
$\begin{array}{l}<400 \mathrm{~m}^{2} \text { (polygonal ponds, } \\
\text { meteoric ponds) }\end{array}$ & 22,783 & 1.564 & 91.0 & 5.9 \\
\hline
\end{tabular}


CORONA satellite images. The DEM data enhanced the mapping process. It was possible to produce high-resolution maps of periglacial features from the CORONA panchromatic imagery.

Quantification of the results within a GIS revealed that thermokarst structures cover more than $50 \%$ of the Bykovsky Peninsula. Their occurrence proves the presence of thick ice-rich deposits. In the Khorogor Valley thermokarst structures occur only in the lowest valley parts, where sedimentary deposits are thick and ice-rich. The pingos of the Bykovsky Peninsula indicate that the taliks below the thermokarst depressions are largely, but not completely, refrozen. According to Schirrmeister et al. (2002), local climate deterioration started around $4500 \mathrm{ka}$ BP with decreasing summer temperatures, decreasing pollen contents and increasing ice-wedge growth. This also suggests that the silting-up and drainage of many of the thermokarst lakes occurred during the Middle- to Late-Holocene. Using the density-slice classification, a fast high-resolution classification of water and nonwater was applied successfully. This approach quantified the vast amount of small water bodies in the tundra landscape. Because such lakes play a major role in methane emission in tundra landscapes, detailed mapping can provide basic information for the quantification of trace gas fluxes from tundra landscapes.

\section{ACKNOWLEDGEMENTS}

The authors would like to thank all Russian and German participants during the expeditions, who helped during the fieldwork. The paper is a result of the German-Russian research cooperation 'System Laptev Sea 2000' supported by the German Ministry of Science and Technology. Thanks to Professor H.M. French and the PPP editorial board for their review and suggested changes.

\section{REFERENCES}

Altmaier A, Kany C. 2002. Digital surface model generation from CORONA satellite images. ISPRS Journal of Photogrammetry and Remote Sensing 56: 221-235.

Andreev AA, Schirrmeister L, Siegert C, Bobrov AA, Demske D, Seiffert M, Hubberten H-W. 2002. Paleoenvironmental changes in north-eastern Siberia during the Late Quaternary-Evidence from pollen records of the Bykovsky Peninsula. Polarforschung 70: $13-25$.
Bindschadler R, Vornberger P. 1998. Changes in the West Antarctic ice sheet since 1963 from declassified satellite photography. Science 279: 689-692

Boike J, Yoshikawa K. 2003. Mapping of periglacial geomorphology using kite/balloon aerial photography. Permafrost and Periglacial Processes 14: 81-85. DOI: 10.1002/ppp.437

Brook RK, Kenkel NC. 2002. A multivariate approach to vegetation mapping of Manitoba's Hudson Bay Lowlands. International Journal of Remote Sensing 23: 4761-4776.

Cabot ES. 1947. The northern Alaskan coastal plain interpreted from aerial photographs. The Geographical Review 37: 639-648.

Czudek T, Demek J. 1970. Thermokarst in Siberia and its influence on the development of lowland relief. Quaternary Research 1: 103-120.

Etzelmüller B, Ødegård RS, Berthling I, Sollid JL. 2001. Terrain parameters and remote sensing data in the analysis of permafrost distribution and periglacial processes: principles and examples from southern Norway. Permafrost and Periglacial Processes 12: 79-92. DOI: 10.1002/ppp.384

French HM. 1974. Active thermokarst processes, eastern Banks Island, Western Canadian Arctic. Canadian Journal of Earth Science 11: 785-794.

Frost RE, Mclerran JH, Leighty RD. 1966. Photo-interpretation in the arctic and subarctic. In Proceedings, First International Conference on Permafrost. National Academy of Sciences-National Research Council of Canada, Publication 1287; 343-348.

Goossens R, De Man J, De Dapper M. 2001. Research on the possibilities of CORONA-satellite-data to replace conventional aerial photographs in geo-archaeological studies, practised on Sai (Sudan). In A Decade of Trans-European Remote Sensing Cooperation, Buchroithner MF (ed.). Balkema Publishers: Lisse/ Netherlands; 257-262.

Grigoryev MN. 1993. Cryomorphogenesis of the Lena Delta mouth area. Permafrost Institute, Academy of Science USSR, Siberian Department. Yakutsk; 1-176 (in Russian).

Grigoriev MN, Rachold V, Bolshiyanov D, Pfeiffer E-M, Schirrmeister L, Wagner D, Hubberten H-W (eds). 2003. Russian-German Cooperation 'System Laptev Sea' The Expedition Lena 2002. AWI Reports on Polar and Marine Research 466: 1-341.

Grosswald MG. 1998. Late-Weichselian ice sheets in Arctic and Pacific Siberia. Quaternary International 45-46: 3-18.

Hope AS, Boynton WL, Stow DA. 2003. Interannual growth dynamics of vegetation in the Kuparuk Riverwatershed, Alaska, based on the Normalized Difference Vegetation Index. International Journal of Remote Sensing 24: 3413-3425.

Kennedy D. 1998. Declassified satellite photographs and archaeology in the Middle East: case studies from Turkey. Antiquity 72: 553-561. 
Kunitsky VV. 1989. Cryolithogenesis of the lower Lena. Permafrost Institute, Academy of Science USSR, Siberian Department. Yakutsk; 1-162 (in Russian).

Leachtenauer JC, Daniel K, Vogl PT. 1998. Digitising satellite imagery: quality and cost considerations. Photogrammetric Engineering and Remote Sensing 64: 29-34.

Leverington DW, Duguay CR. 1997. A neural network method to determine the presence or absence of permafrost near Mayo, Yukon Territory, Canada. Permafrost and Periglacial Processes 8: 205-215.

Lewkowicz AG, Duguay CR. 1999. Detection of permafrost features using SPOT panchromatic imagery, Fosheim Peninsula, Ellesmere Island, N.W.T. Canadian Journal of Remote Sensing 25: 33-44.

Mackay JR. 1962. Pingos of the Pleistocene Mackenzie Delta area. Geographical Bulletin 18: 21-63.

Meyer H, Dereviagin AY, Siegert C, Hubberten H-W. 2002. Paleoclimatic studies on Bykovsky Peninsula, North Siberia-hydrogen and oxygen isotopes in ground ice. Polarforschung 70: 37-51.

Mollard JD. 2000. Ice-shaped ring-forms in Western Canada: their airphoto expressions and manifold polygenetic origins. Quaternary International 68-71: 187-198.

Morrissey LA, Strong L, Card DH. 1986. Mapping permafrost in the boreal forest with thematic mapper satellite data. Photogrammetric Engineering and Remote Sensing 52: 1513-1520.

Murton JB. 1996. Thermokarst-lake-basin sediments, Tuktoyaktuk coastlands, western arctic Canada. Sedimentology 43: 737-760.

Peddle DR, Franklin SE. 1993. Classification of permafrost active layer from remote sensed and topographic evidence. Remote Sensing of Environment 44: 67-80.

Philip G, Donoghue D, Beck A, Galiatsatos N. 2002. CORONA satellite photography: an archaeological application from the Middle East. Antiquity 76: 109118.

Rees WG, Williams M, Vitebsky P. 2003. Mapping land cover change in a reindeer herding area of the Russian Arctic using Landsat TM and ETM+ imagery and indigenous knowledge. Remote Sensing of Environment 85: 441-452.

Rigina O. 2003. Detection of boreal forest decline with high-resolution panchromatic satellite imagery. International Journal of Remote Sensing 24: 1895-1912.

Romanovskii NN, Hubberten H-W, Gavrilov AV, Tumskoy VE, Tipenko GS, Grigoriev MN. 2000. Thermokarst and land-ocean interactions, Laptev Sea region, Russia. Permafrost and Periglacial Processes 11: $137-152$.

Schirrmeister L, Siegert C, Kunitsky VV, Grootes PM, Erlenkeuser H. 2001a. Late Quaternary ice-rich permafrost sequences as a paleoenvironmental archive for the Laptev Sea Region in northern Siberia. International Journal of Earth Sciences 91: 154-167.

Schirrmeister L, Kunitsky V, Grosse G, Kuznetsova T, Kuzmina S, Bolshianov D. 2001b. Late Quaternary and recent environmental situation around the Olenyok Channel (western Lena Delta) and on Bykovsky Peninsula. In Russian-German Cooperation 'System Laptev Sea 2000' The Expedition Lena 2000, Rachold V, Grigoryev M (eds). AWI Reports on Polar and Marine Research 388: 85-135.

Schirrmeister L, Siegert C, Kuznetsova T, Kuzmina S, Andreev A, Kienast F, Meyer H, Bobrov A. 2002. Paleoenvironmental and paleoclimatic records from permafrost deposits in the Arctic region of Northern Siberia. Quaternary International 89: 97-118.

Siegert C, Schirrmeister L, Kunitsky VV, Meyer H, Kuznetsova T, Derevyagin S, Kuzmina S, Tumskoy V, Sher A. 1999. Paleoclimate signals of ice-rich permafrost. In Russian-German Cooperation 'System Laptev Sea 2000' The Lena Delta 1998 Expedition, Rachold V, Grigoryev M (eds). AWI Reports on Polar and Marine Research 315: 145-259.

Siegert C, Schirrmeister L, Babiy O. 2002. The sedimentological, mineralogical and geochemical composition of Late Pleistocene deposits from the Ice Complex on the Bykovsky Peninsula, Northern Siberia. Polarforschung 70: 3-11.

Soloviev PA. 1973. Thermokarst phenomena and landforms due to frostheaving in Central Yakutia. Biuletyn Peryglacjalny 23: 135-155.

Stow DA, Hope A, McGuire D, Verbyla D, Gamon J, Huemmrich F, Houston S, Racine C, Sturm M, Tape K, Hinzman L, Yoshikawa K, Tweedie C, Noyle B, Silapaswan C, Douglas D, Griffith B, Jia G, Epstein H, Walker D, Daeschner S, Petersen A, Zhou L, Myneni R. 2004. Remote sensing of vegetation and land-cover change in Arctic tundra ecosystems. Remote Sensing of Environment 89: 281-308.

Tappan GG, Hadj A, Wood EC, Lietzow RW. 2000. Use of Argon, Corona, and Landsat Imagery to assess 30 years of land resource changes in west-central Senegal. Photogrammetric Engineering \& Remote Sensing 66: 727-736.

Tommervik H, Hogda KA, Solheim I. 2003. Monitoring vegetation changes in Pasvik (Norway) and Pechenga in Kola Peninsula (Russia) using multitemporal Landsat MSS/TM data. Remote Sensing of Environment 85: 370-388.

Walker DA. 1999. An integrated vegetation mapping approach for northern Alaska (1:4 M scale). International Journal of Remote Sensing 20: 2895-2920.

Yoshikawa K, Hinzman LD. 2003. Shrinking thermokarst ponds and groundwater dynamics in discontinuous permafrost near council, Alaska. Permafrost and Periglacial Processes 14: 151-160. DOI: 10.1002/ ppp.451 